\begin{tabular}{lcc}
\hline Volume 1 & Number 13 & 18 SEPTEMBER 2016 \\
\hline
\end{tabular}

\title{
CHRIS OLSON
}

\section{THE GOOD EGG ${ }^{1}$}

What was to be done with the acquisition of a 20-unit restaurant company: The Good Egg?

"Now what?" Ken pondered as he stared out the window on his flight back from Phoenix having just closed on the acquisition of a 20-unit restaurant company: The Good Egg. Ken Pendery, the CEO of the First Watch restaurant chain for the last 30 years, had just recently grown the company by $20 \%$ in one fell swoop. But what was he to do with these Arizona restaurants located more than 1,000 miles from the nearest company-owned First Watch...convert them to First Watch, leave them be, institute the First Watch menu but leave The Good Egg flag...?

Ken understood that the decision regarding what to do with The Good Egg brand would have far-reaching consequences. The purchase and conversion to First Watch of two J. Christopher's restaurants in Atlanta 18 months earlier had not gone as planned. Part of the predecessor's loyal customer base defected, sales fell by nearly $20 \%$, and the company struggled for the next year to restore sales and profits to preconversion levels. If The Good Egg were to have the same fate upon conversion, the results would be devastating for the company and the management team. Recognizing that The Good Egg was the most highly-penetrated breakfast, brunch, and lunch brand with 15 locations in Phoenix and 5 in Tucson as well as a 30-year operating history made the decision even more precarious.

The reasons for conversion were clear in Ken's mind. First Watch had 10\% higher average unit sales volumes than The Good Egg. Additionally, having 20 newly-converted First Watch restaurants would provide a foothold in the West, further expanding the brand's presence. Finally, upon the inevitable sale of First Watch by its private equity group, the valuation of First Watch would be enhanced if those 20 restaurants were converted to First Watch as opposed to selling two disparate brands.

Allowing The Good Egg to simply continue to operate independently would provide a predictable, stable revenue and profit stream, and remove the possibility of conversion loss as was realized in Atlanta. Straying from this strategy posed the possibility of considerable upside potential, but also significant downside risk.

This would be one of the most pivotal decisions Ken would have to make as CEO and the decision consumed him for the remainder of his 5-hour flight back to Sarasota.

\footnotetext{
${ }^{1}$ Copyright $@$ 2016, Chris Olson. This case was prepared for the purpose of class discussion, and not to illustrate the effective or ineffective handling of an administrative situation. Names and some information have been disguised. This case is published under a Creative Commons BY-NC license. Permission is granted to copy and distribute this case for non-commercial purposes, in both printed and electronic formats.
} 


\section{U.S. Restaurant Industry}

Today's food service industry is a result of the industrial revolution (see Exhibit 1). Technological advances made possible the mass production of food products, speedier distribution of goods, climate controlled storage facilities, and more efficient cooking appliances. New and emerging methods of transportation (trains, automobiles, and trucks) created a significant demand for public dining establishments (www.foodtimeline.org/restaurants).

Beginning in the early 1970s, women began working outside the home at an increasingly higher rate which had a direct effect on food spending away from the home (see Exhibit 2). Young families with dual incomes but little time used restaurants as a replacement to cooking at home. This changing demographic created strong demand for the restaurant industry fueling increases in both sales and restaurant outlets through the 1980s and 1990s. In the early to mid-2000s, the percentage of women in the workforce peaked and then started to decline. Decreasing along with this was the rate of change in restaurant samestore-traffic as restaurant supply began to exceed restaurant demand. Same-store-traffic was a key metric in the restaurant industry defined as the percentage change in visitation for all restaurants open in the current and prior year.

By 2014, the restaurant industry was the $2^{\text {nd }}$ largest private sector employer with 14 million employees and industry sales topping $\$ 700$ billion. There were over 1 million restaurant locations in the United States where spending accounted for over $50 \%$ of every food dollar spent (National Restaurant Association).

While it was sometimes difficult to distinctly categorize a restaurant brand and its food and service offerings, the restaurant industry could be subdivided into two classes, limited service and full service, and a number of different segments within each class.

\section{Limited Service Restaurants}

Limited service restaurants comprised 55\% of industry sales and included the quick service segment and the recently emerged fast casual segment.

\section{Quick Service}

Quick-service (fast food) restaurants provided foodservice where patrons generally ordered or selected items and paid before eating. Food and drink could be eaten on premises, taken out, or delivered. The average per-person dinner was \$3-\$6. Examples of traditional quick-service restaurants included: Pizza Hut, Taco Bell, KFC, Hardee's, Wendy's and Carl's Jr. While the quick service segment's share of limited service sales at $85 \%$ dwarfed that of its newer member, they had been consistently losing share to this emerging fast casual segment.

\section{Fast Casual}

The burgeoning fast-casual segment of restaurants served freshly prepared, wholesome quality, authentic foods in a reasonably fast service format. The average per-person dinner was \$7-\$9. Examples of fastcasual restaurants included: Chipotle, Five Guys, Panera, Panda Express, and Pei Wei. While making up only $15 \%$ of limited service sales, fast casual restaurants had seen their sales growth consistently outpace that of quick service and continued to steal their market share as consumers clamored for a better limited service experience. 


\section{Full Service Restaurants}

Full service restaurants made up the balance of industry sales at $44 \%$ (save $1 \%$ for the bar/tavern category) and included the family dining, casual dining and fine dining segments.

\section{Family Dining}

Family dining full-service restaurants provided serving staff and orders were taken while the patron was seated. The average per-person dinner was $\$ 10$ or less. Members of this group were fairly diverse and included 24-hour operations, diners, daytime-only restaurants, and budget steakhouses. Examples of this segment included: IHOP, Denny's, The Egg \& I, Steak-n-Shake, First Watch, and Ponderosa.

\section{Casual Dining}

Casual dining full-service restaurants provided serving staff and the order was taken while the patron was seated. The average per-person dinner was \$10- \$25. Examples of this segment included: Chili's, Olive Garden, Red Lobster, TGI Friday’s, Macaroni Grill, and Outback Steakhouse. The casual dining segment was hit hard by the great recession and, coupled with the emergence of the fast casual segment, had seen same-store-traffic declines of $2 \%$ per year since 2009. To compete, this segment relied heavily on discount promotions (i.e., buy one get one free/2 for \$20) and limited time menu offerings.

In terms of price point, the top end of this segment had been further defined with the tag of "polished" casual dining. Examples of polished-casual restaurants included: Bonefish Grill, Season's 52, Brio, Kona Grill and Houston's.

\section{Fine Dining}

Fine dining full-service restaurants provided serving staff and the order was taken while the patron was seated. The average per-person dinner was \$25 or more. Examples of fine dining restaurants included: Ruth's Chris Steak House, McCormick \& Schmick's, Morton's Steakhouse and Ocean Prime. This smallest player in full service restaurants was hit hardest by the great recession with negative traffic in the mid to high teens in consecutive years, but has since rebounded (along with the stock market) to prerecession traffic levels.

\section{Breakfast, Brunch and Lunch Sub-Segment}

Also known as the "daytime-only" sub-segment of the Family Dining segment, the breakfast, brunch and lunch ("BBL") sub-segment was characterized by restaurants that were open only for the breakfast, brunch and lunch meal periods and elected to forego offering dinner service often closing by late afternoon and operating $71 \frac{1}{2}$ to 8 hours a day.

\section{First Watch Restaurants, Inc.}

The company's name was based on a nautical term used in dividing the 24-hour work day on a ship into six four-hour "watches:" middle watch, morning watch, forenoon watch, afternoon watch, dog watch, and first watch. Ironically, the first watch begins at 8:00 p.m. and ends at midnight, yet First Watch was a daytime-only café. First Watch operated in the breakfast, brunch and lunch sub-segment operating between the hours of 7:00 a.m. and 2:30 p.m. 


\section{Company Overview}

First Watch was a full-service restaurant chain operating in the family dining segment of the restaurant industry. First Watch specialized in award-winning, made-to-order breakfast, brunch and lunch including traditional favorites, such as omelets, pancakes, sandwiches and salads, and unique specialty items like the Chickichanga, Pesto Chicken Quinoa Power Bowl and Fresh Fruit Crepes (see Exhibit 8). All menu items were freshly prepared to order and the restaurant did not use deep fryers or heat lamps. The entire menu was available seven days a week from 7:00a.m. to 2:30p.m. Guests were offered complimentary newspapers and free Wi-Fi Internet access (http://www.firstwatch.com/).

The first restaurant opened in 1983 in Pacific Grove, California. At that time, there was no breakfast restaurant-focused category. The company was founded by John Sullivan, a restaurant veteran and cofounder of Le Peep Cafe, also a breakfast, brunch and lunch concept founded in Denver, CO in 1981. One of those co-founders, Ken Pendery, joined John Sullivan in opening the second First Watch and remained as First Watch's CEO for over 30 years.

In 2014, First Watch was the largest and fastest-growing daytime-only restaurant concept in the U.S. with more than 130 restaurants in 17 states (see Exhibit 7). It also operated 20 restaurants under The Good Egg name in Arizona and one Bread \& Company restaurant in Nashville with another under development.

First Watch has received more than 200 "Best Breakfast" and "Best Brunch" awards. The company was named a 2013 “Next 20” Emerging Brand by Nation's Restaurant News, a 2014 Top Franchise Value by FSR Magazine, the recipient of the 2014 MenuMasters Award for Best Healthful Innovation for its Quinoa Power Bowl and was the 2015 Consumer Picks award winner in the family dining segment from a Nation's Restaurant News survey (see Exhibit 3 and Exhibit 6).

\section{Strategic Plan}

In December 2011, a majority interest in First Watch Restaurants, Inc. and Subsidiary was purchased by Freeman Spogli, a private equity firm (see Exhibit 4). At that time there were 79 company-owned restaurants and 12 franchise-owned restaurants in 13 states.

The company's five-year plan developed shortly thereafter called for growing company-owned restaurants to 200 locations and growing franchised-owned restaurants to 100 locations. Company-owned development goals would be achieved through a mix of acquisitions and organic growth--sourcing real estate, negotiating leases and making investments in furniture, fixtures, and equipment as well as improving the leased space. Acquisitions could involve acquiring a lone operating restaurant, an operating restaurant company with multiple locations which may or may not be a direct competitor, or simply acquiring a lease from a tenant with suitable space to build-out a restaurant. Franchise development goals would be achieved through existing franchisees fulfilling the development commitments outlined in their franchise agreement, and selling additional franchise territories and development rights to prospective franchisees.

Demonstrating the ability to grow the number of restaurant outlets, particularly in new states, was pivotal to enhancing the company's ultimate value. In addition, being able to grow a stable and comparatively less risky stream of royalty payments would inordinately enhance the company's valuation multiple.

\section{The Good Egg Acquisition}

In mid-2013, the company was presented with an opportunity to purchase a 20-location, breakfast, brunch, and lunch restaurant chain located in Arizona called The Good Egg. The Good Eggs were fullservice restaurants operating in the family dining segment of the restaurant industry and were open 
between the hours of 6:30a.m. and 2:30p.m. Founded in 1983, the company grew to 15 restaurants in metro Phoenix and five others in southern Arizona over a 30-year period. The principal of the closelyheld company was interested in monetizing his long-held investment and pursuing new investment opportunities.

The acquisition opportunity fit well with the company's strategic plan of growth through acquisition and the company felt that the underlying real estate for The Good Egg restaurants was superior to that of First Watch. However, the company also believed that having "egg" in the brand name served to stymie lunch sales and that their lunch offerings could be more compelling (see Exhibit 9). In addition, The Good Egg catered to an older demographic while First Watch was seeking to attract younger diners with a more contemporary menu and fresh look with its "urban farm” remodel program.

Following exhaustive due diligence, the company closed on the acquisition in February 2014.

\section{Post-Acquisition Options}

\section{Convert to First Watch in Every Way but Trade Name}

One option for First Watch was to capitalize on the equity in The Good Egg name, but make it like a First Watch in all tangible respects. It could serve First-Watch food (with The Good Egg name on the menu) in a First-Watch-looking dining room (with a The Good Egg sign on the building) and also keep The Good Egg operating hours. This approach would avoid the potential of alienating its loyal customer base and impinging on the brand pride felt by its employees. Additionally, this would allow First Watch to further leverage its purchasing power (see Exhibit 5).

\section{Convert to First Watch in All Respects}

The Arizona market was not without First Watch restaurants. As many as four licensed First Watch restaurants had been in operation in the Phoenix/Scottsdale area over the last 30 years with three in operation as of 2014. The licensee was a former partner of Mr. Pendery in the original First Watch restaurant and secured rights to license the brand in the greater Phoenix area while Mr. Pendery headed east to plant the First Watch flag in Sarasota, FL in 1986. While not under the stricter supervision of a franchised First Watch restaurant, the brand was, at least, already established in the "Valley of the Sun" and enjoyed comparable average unit sales volumes as The Good Egg.

With 20 additional First Watch restaurants in Arizona, the company would further establish its presence in Arizona and the western United States, and could leverage its scale related to purchasing, advertising, human resources and accounting costs. In addition, upon the ultimate sale of the company to private investors or a public offering, the company would likely garner a higher valuation with a homogenous company of First Watches versus a portfolio of disparate "BBL" concepts. Finally, the typical First Watch restaurant enjoyed 10\% higher sales than its The Good Egg counterpart. And those higher sales carried with them a $40 \%$ marginal profit rate.

\section{Hybrid Approach}

Given the total number of restaurants being acquired and in two distinct markets, the company could engineer a test to ascertain the effect of changing any or all components of one or more of The Good Egg restaurant locations. It could convert three restaurants in all respects, and convert three others in all but trade name and then monitor traffic and consumer perceptions versus the remaining unchanged 
restaurants (control group). This approach would serve to reduce the exposure to an unfortunate reaction by loyalists, while also lowering the amount of capital being put at risk.

\section{Do Nothing}

There was no impending reason to convert The Good Egg to First Watch. The Good Egg was highlypenetrated in Phoenix and Tucson with a recognizable brand name, was well-trafficked, and had significant sales and cash flow. Being in the BBL segment, The Good Egg's offerings and service style were similar enough to that of the company such that it could still bring operational expertise and purchasing synergies to The Good Egg under its current moniker. Under this alternative, the company would also avoid the capital expense of converting trade dress and signage to that of First Watch.

\section{Summary}

The acquisition of The Good Egg was not the company's first acquisition. In the fall of 2012, the company acquired two J. Christopher's restaurants in suburban Atlanta, GA--the company's first restaurants in the Atlanta market. A significant part of the predecessor's loyal customer base immediately defected and migrated to remaining J. Christopher's in the market. Some customers did not even bother entering the building once they saw the new sign. Certain employees' morale also soured as they donned a new polo emblazoned with First Watch, a brand previously foreign to them. As a result, sales fell nearly $20 \%$ and the company struggled over the next year to restore sales and profits to pre-conversion levels.

The question of what to do with The Good Egg was profound. The Good Egg represented 20\% of the overall company and First Watch now owned an Arizona institution having served two generations of families in Phoenix. The geographic challenge of being a thousand miles away from the nearest companyoperated First Watch was also a consideration and converting 20 restaurants to First Watch would pose a human resource challenge.

The upside, though, was clear. Without "egg” in the name, First Watch restaurants garnered 10\% higher average unit sales predominately from lunch. In addition, having a homogenous portfolio of restaurants would certainly help with the exit valuation.

\section{Biography}

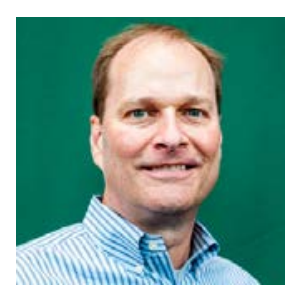

Chris Olson is the Senior Vice President of Finance at First Watch Restaurants, Inc. and a life-long student of the restaurant industry. He is currently enrolled in the Doctorate of Business Administration program at the University of South Florida. He received his M.B.A. from the University of Texas at Dallas and his undergraduate degree in Finance from Oklahoma State University. Olson is also a Certified Public Accountant licensed in the State of Florida. 


\section{Exhibit 1: History of the Restaurant}

\section{Origin}

Derived from the French word restaurer, to restore, the origin of restaurants is credited to $18^{\text {th }}$ century France. The first French restaurants were unassuming, highly-regulated establishments that sold restaurants; meat-based consommés intended to "restore” a person's strength if feeling ill. After the French Revolution, the monopolistic rights of the restaurant guild, which had been under license by the king since the Middle Ages, were abolished forcing the former chefs of the aristocrats to find new work serving the working masses. This development stirred the demand of French citizens who embraced the principal of egalitarianism knowing anyone could purchase a given meal if willing to pay the price. Enterprising French chefs capitalized on this swell by offering portioned dishes, prepared and priced to order, and merchandised on menus. The modern restaurant was born.

Source: http://www.foodtimeline.org/restaurants.html 
Exhibit 2: Influence of Women in the Workforce on Restaurant Sales

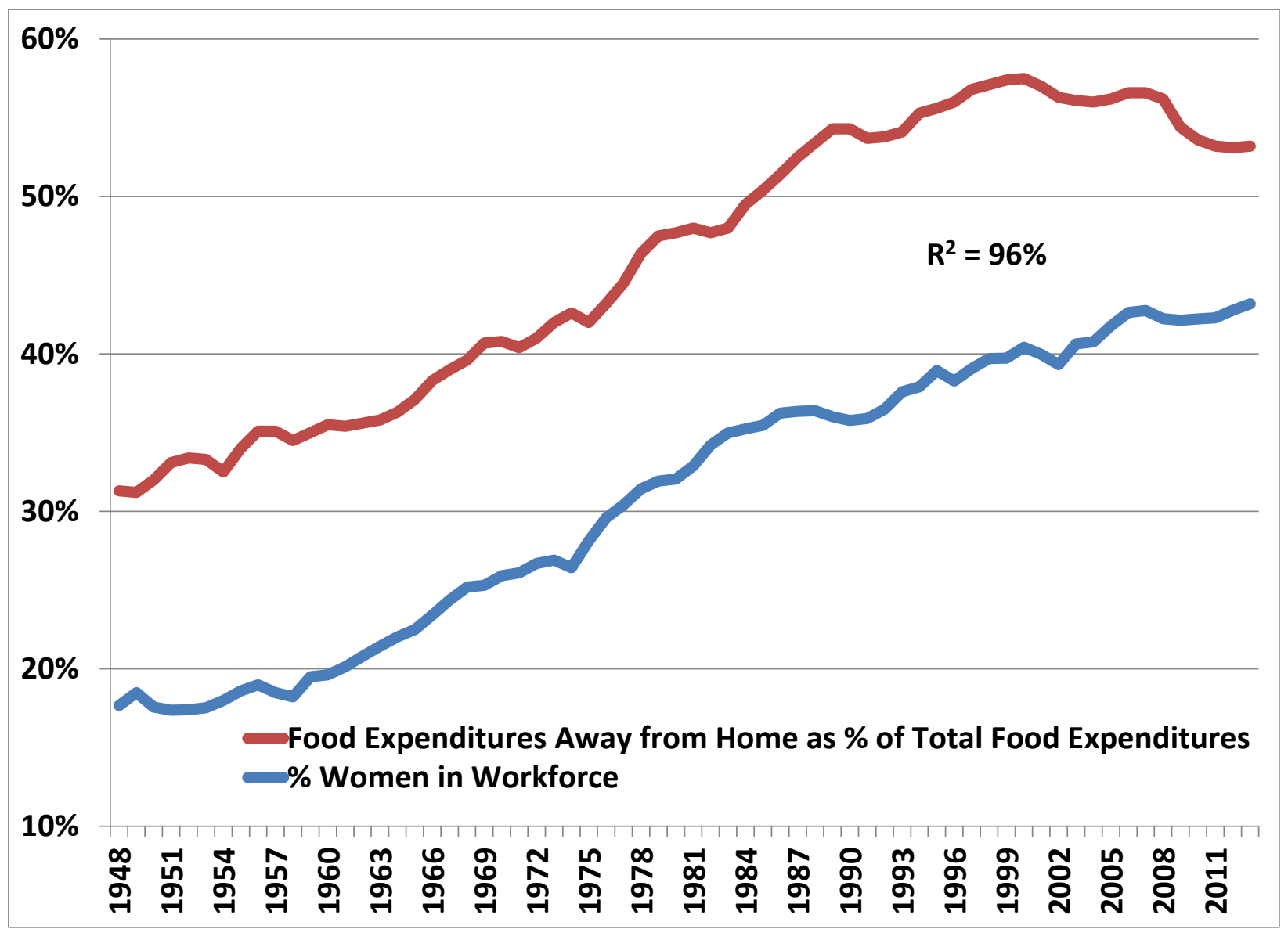

Source: Developed by case writer. 
Exhibit 3: National \& Regional Competitors in the Breakfast, Brunch and Lunch Sub-Segment ("BBL")
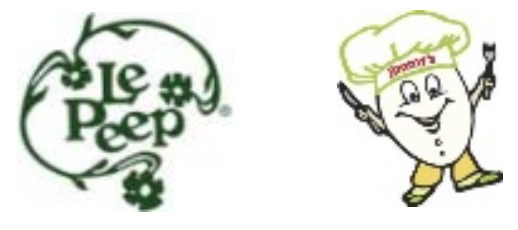

\section{Good Egg $_{\text {IHE }}$}

Year

Founded Restaurants

Name

Le Peep

Jimmy's Egg

First Watch

The Good Egg

Egg Harbor Café

Egg \& I

Another Broken Egg

J. Christopher's

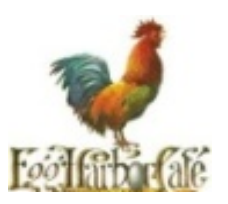

1970

1980

1983

1983

1985

1987

1996

1996

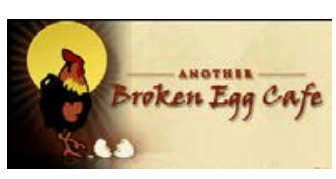

54

42

126

20

18

115

48

22

445

Source: Developed by case writer. 


\section{Exhibit 4: Freeman Spogli \& Co.}

\section{FS Freeman Spogli \& Co.}

Freeman Spogli is a leading private equity firm dedicated to investing with management in middle market companies in the consumer and distribution sectors.

Our firm was founded by Bradford M. Freeman and Ambassador Ronald P. Spogli in 1983 with the goal of investing capital in partnership with management teams to help build growth-oriented companies. Mr. Freeman and Ambassador Spogli were among the pioneers in the private equity business and raised the firm's first institutional equity fund in 1986. In its three decades in business, our firm has grown to over 25 employees in two offices and has invested $\$ 3.4$ billion of private equity capital in 51 companies. We currently manage four investment funds totaling $\$ 4.0$ billion in committed capital and have investments in 14 companies with total sales of $\$ 10$ billion.

Criteria for Investment

Industry:

- Established companies in the consumer and distribution industries

- Includes retail, restaurants, direct marketing, e-commerce, consumer products, retail services and wholesale and business-to-business distribution

Transaction Types:

- Management buyouts, leveraged recapitalizations, corporate carve-outs and equity investments

Company Characteristics:

- Strong management teams

- Defensible market positions

- Platform for organic and acquisition growth

- Solid margins and free cash flow

Geography:

- North America

Company/Transaction Size:

- Companies with EBITDA of $\$ 10$ million to $\$ 75$ million

- Equity investments of $\$ 50$ million to $\$ 150$ million

- Transactions of $\$ 100$ million to $\$ 750$ million in total size

Source: http://www.freemanspogli.com/ 


\section{Exhibit 5: Brands with Identical/Similar Offerings and Different Names}

\section{Restaurants}

The notion of operating identical brands in all material respects but name is not a new phenomenon. After a 1999 merger between Checker's and Rally's, Rally's adopted the Checker's design and since then both Checker's and Rally's continued to offer a limited menu, had a similar restaurant design with a double drive through, and had very similar menu offerings.

In 1997 the parent company of Carl's Jr. purchased Hardees. Both brands operated in the quick-service segment of the restaurant industry and catered to young males with significant appetites. Eventually, their trade dress and menu offerings became identical although they maintained a separate brand name.

\section{Packaged Goods}

In 1932, Best Foods bought its East coast rival, Hellman's Mayonnaise. Both companies maintained their separate brand identities, as both had large market shares in their respective regions. It was not until 1968 when Best adopted the blue ribbon of Hellman's, thus, merging the logos in all but name. To this day, both brands use the same commercials and advertisements but with switched names. Both products have the same ingredients, but loyalists swear to a different taste.

Masters Dreyer and Edy founded Edy's Grand Ice Cream in 1928. When Mr. Edy left the business in 1947, Mr. Dreyer renamed the company in his likeness. When the company expanded to the East coast in 1981, the company decided to resurrect the trade name Edy's so as not to confuse the brand with an East coast brand, Dreyer's. To this day, the company operates under both brands in all respects but brand name.

Orowheat was founded in Hollywood, CA in 1932. Arnold Bakery was founded in Connecticut in 1940. In 1946, Brownberry was founded in Wisconsin. Arnold, Brownberry and Orowheat breads were all purchased by Bimbo Bakeries in the 2000's. While all have distinct histories, they all now operate as divisions of Bimbo Bakeries, USA. 

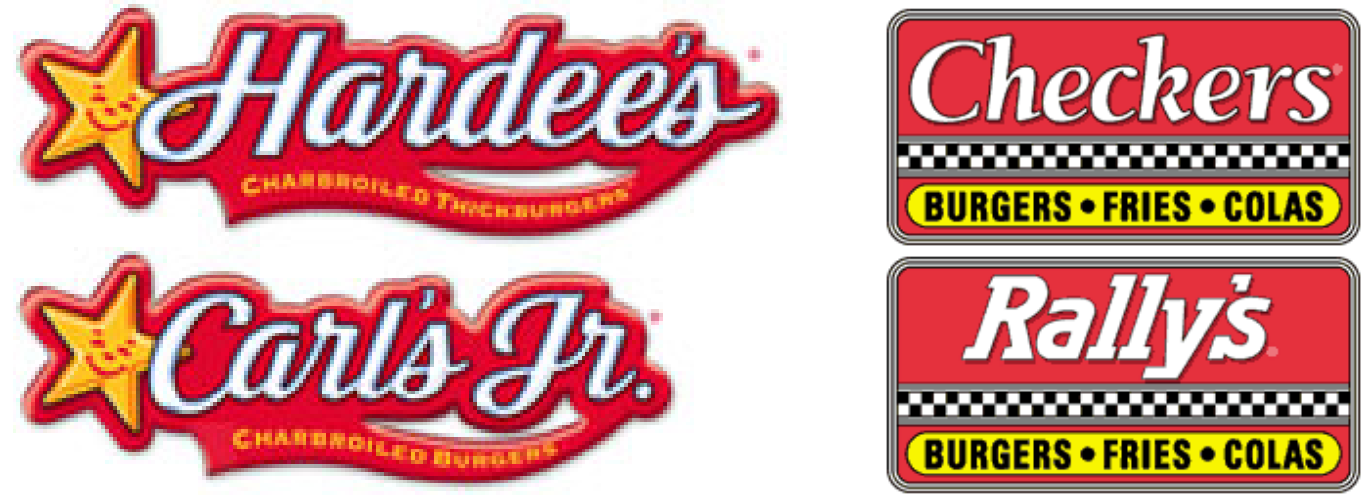

$$
\text { गैब }
$$

'BRING OUT THE BEST'
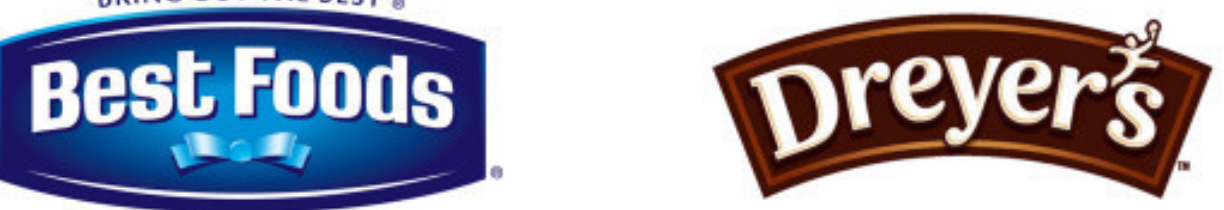

'BRING OUT THE BEST'

\section{HELLMAN'S}

Best Foods/Hellmann's

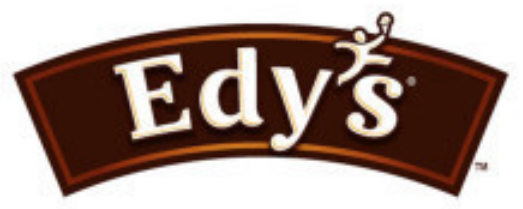

Dreyer's/Edy's

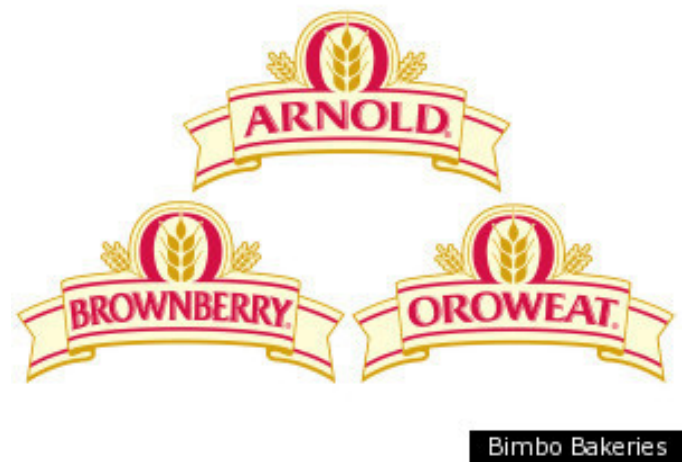

Source: Developed by case writer. 


\section{Exhibit 6: First Watch Accolades}

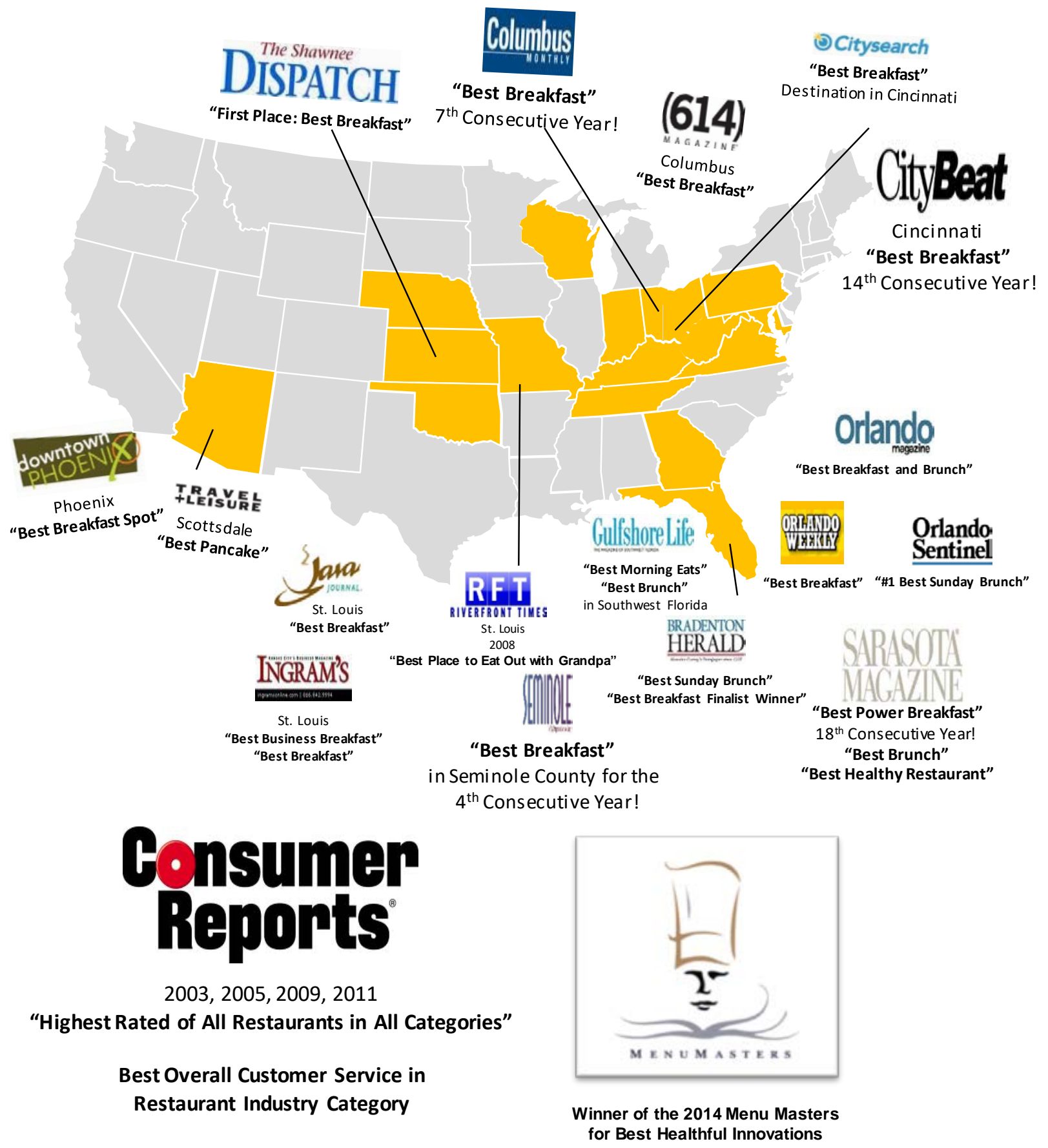

Source: Developed by case writer. 


\section{Exhibit 7: First Watch Footprint - 2014}

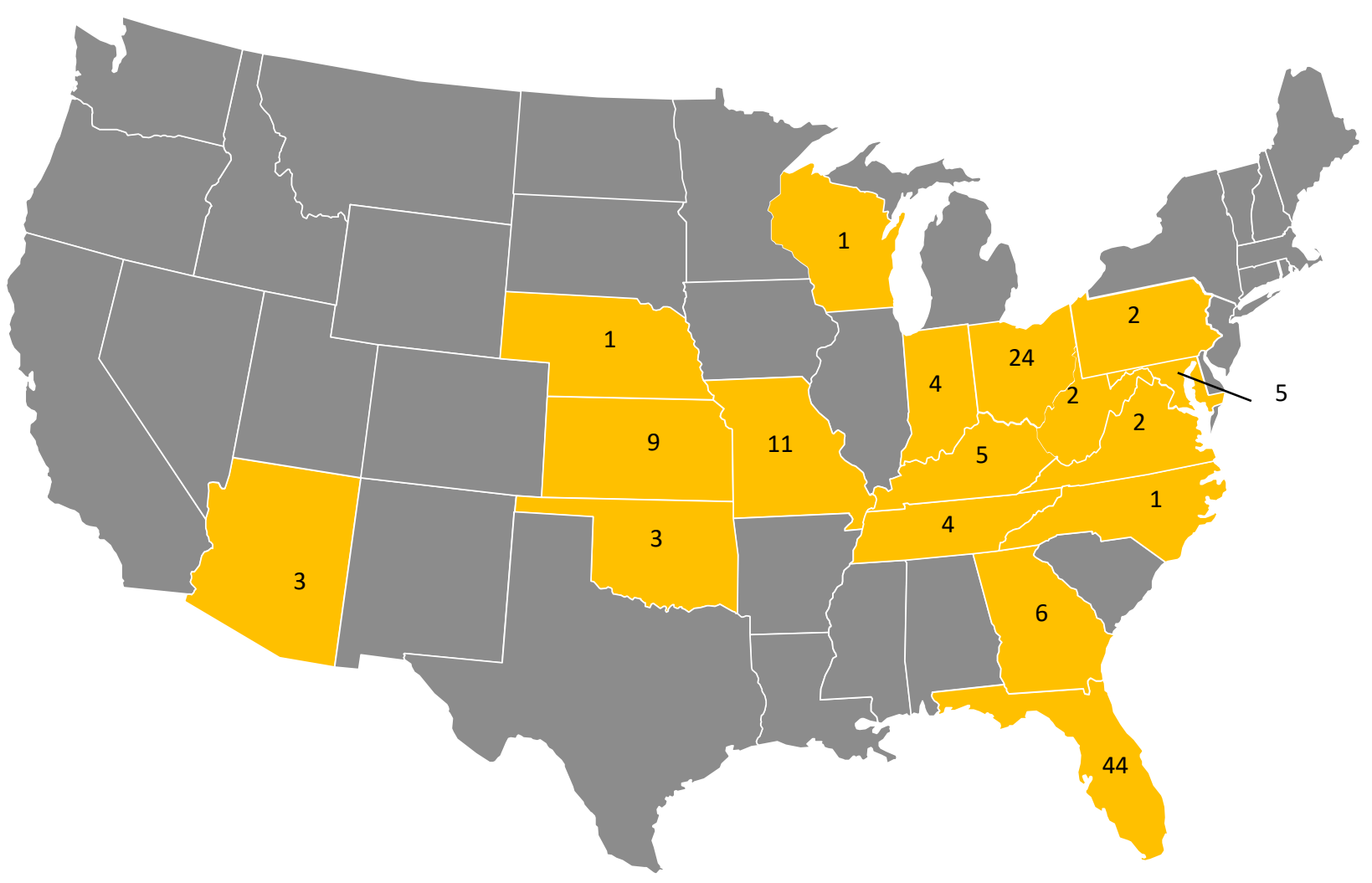

Source: Developed by case writer. 
Exhibit 8: First Watch Menu

$\overline{\text { THE DAYTIME CAFE }}$ ए

-WB PROUDLY FEATURE FRESH GEASONAL PRODUCE PROM LOCAL OROWERS WHENEVER POSSTBLE -

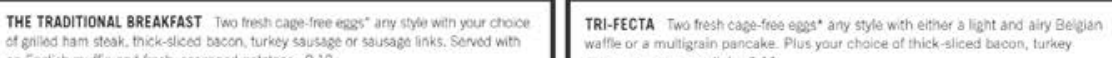
an Engish muffin and fresh, seasoned potsibes. 8.19

sausage or sausage link. 8.19

\section{OMELETS}

Served with either dressed greens $\mathrm{OR}$ fresh, seasoned potatoes and an English muffin. Cholesterol/fat-fre additional charge.

BACADO Broon, avocado and Monterey Jack. Topped with sour oream and sorved with a kido of

ACAPULCO EXPRESS Chorizo sausage, avocado Monterey Jack. Topped with sour creatin and served

GREEK PETISH Roanted red poppers, appinnoth
and onions with fota and blackic ollves. 8.69

VEG'D OUT House-roastod Crimini mushrooms, zucchini, onions, tomatoos and brocsoli with
Cheddar and Monterey Jack. 8.59

VIA VENETO Italinn sauisage, house-roasted tomatoes and red peppers with froen herbs.

THE wORKS Ham, bacon, sausage, houlso-rossted Crimini mushrooms, ontons and tomatoos with

Cheddar and Monterey Jnck. Topped with so

swisshroOM Ham, house-roasted Crimini mush-

\section{THE HEALTHIER SIDE}

ENERGY BOWL Your etoice of our bousemate gramola or Muesili corcal of ants, alicod almonds, with fresh fruit and a toroh of oinnamion. Sorved with low-fat organic yogurt. 5.19

SIESTA KEY COCKTAIL A bealthy parfait of vanills and strawberry low-fat organio yogurt, fres a fresh baked muftin of tho day. 7.39

TRI-ATHLETE Egg whito omelet with housogrven chiliteas. Served with housemade salea, a dry Englisht tnuffin and frosh frust. 7.90

POWER WRAP Egg whites, turkey, spinach fruit and a sicle of housemade salean. 8.19

HEALTHY TURKEY Bgg white omelet with turzey, bouse-roastod onions, tomatoos, spinach and
feta. Served with a dry English muffin. 8.19 CRANBerRy NUT OATMRaL Mado to ordor with oranberrins, Georgin pocans and sliced banara English muffin. 5.19 Ptain 4.78

FRESH FRUTT CREPES Two thin, swoot oropes

wrippod around frosh fruif, toppod with low-fat murfin of the day and hougemade granolia. 7.89

\section{EGGS-CLUSIVES THE MIDDLE GRIDDLE}

CHICKICHANGA Whipped eggs with spicy all-

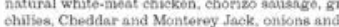

avocendo rolled in a flour tortilla. Topped with Ver Cruz sance and sour cream. Served with fresh fruit and Irosest, sansonod potatoos. 9.50

KEY WEST CREPEGGS A thin erepo lasyored with Trosh 68 sss, turkey, avocado, baonon, tomatoes and with an English muffin, a side of houssomnde talan and frosh, soasoned potatoog. 8.99

EGGS BENEDICT TWo ponched Cage-froo egrs" atop a towated English muftin pisod high with your thaco

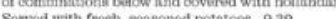
- Hrm and tomato

- Florentine - fresth spinach, avoosdo and tomato BREAKFAST SCRAMBLI. Freesh, sorambled cag" froo eggs, spinach, ham and moltod Choddar ar Monterey Jack on multigrain tonst Toppod with toolianclaise and served with fresth fruit and frezh. sonsonod potatcoss. 8.30

MULTigrarn paycakes

Theas besalde paxcaks a we votta warn you

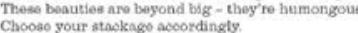

- Plain - Wheat Germ

: Btuoborry

- Banana Granola Crunch - Pocan

- Bacon and Cheddar

One 3.89 Two 5.19 Three 6.59

BELGIAN WAFPLE Our light and airy wame with

a sicice of wartm, mixod borry oompote. 6.89

FLORIDIAN FRENCH TOAST Sourdough Fronech toast with whoat gorm and powdorod
einnumon sugar, covered with fresh bansna, kivi and aeasonal berries. 8.79

PRENCH TOAST Your elowice of sourdougb or raisin bread. Toppod with oreamy butter and

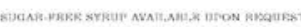

FRENCH TOAST MONTE CRISTO Housomado sourdoctgh prench toast layered with baill, turkey. melted Swisu and erenmy Dijonnaise grilled to perketson ind dustad with powdertad cinnamon preserves for dipoing 939

\section{HASHES}

AVOCADO, BACON AND TOMATO HASH TWO

frosh ongo-froo orger" any stylo atop frosh, moasoned

Choddar and Montoroy Jack. 9:18

BACON AND ONION HASH Two frosl cago-froo

eggs" any style atap fresh., seasoned potators

Cheddur and Monterey Jack. 9.19

MARKET HASH Two freab eage-free eggrt

any atyle atop frosh, seasoned potatoos, housc
ronated Crimini munhmooms, zucchini, onione

and red peppors with spinach, meitod mozzarell and herbed goat obeese. 9.10

PARMA HASH Two freah eage-free egg" any

ed potatoes, Italian nuusage, house-roanted Crimini munhtroomn, onjons and tomatoos with molted Parmesan. mozzarelin and fresh herbs. 9.49

\section{POWER BOWLS}

PESTO CHICKEN QUINOA BOWL Proteinpackoed quinoan, kate, shredded carrots and houso lemon ehickon breast, breil pesto sacco, fota crumbles and treali therth, 8.39

CHERRY CHICKEN QUINOA BOWL Protein-

packod quimon, houso-ronstod zucohimi, drived

cherries, all-batural white-meat chicken breast and

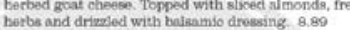

.




\section{SANDWICHES}

Sandwiches served with dressed greens or a bowl

of hot soup.

MONTEREY CLUB Turkey, bacon, arocado, lettuce, tomato,
multigrait. 8.69

BAJA TURKEY BURGER A lean white-meat turkey patty with avoeado, lettuoe, housemade saijac
mayo and Popper Jack on a grilled wheat bun. 8.18

CHCKEN PALERMO Orilled all-natural waitoweat chickon, sticed tomato, onion. pepperoncini and motzarella with basil pesto and mayo on artisan
eiabatta. 8.89

REUBEN Corned beef or turkey on grilled rye with Thousand island, sauerkraut and \$wiss. 8.19

BEEFEATKR Roaat beet, tomato, Choddar

and Monterey Jack on grillod Parmenan-oruatiod
nourdough. Horserndish sauce on the side. 8.99

VEGGIE GRILL House-roasted Crimini

mushrooma, zuochini and spinach with basil posto,
mayo and moltod Swiss on grillod multigrain.

\section{SALADS}

NOT GUITTY YOUR BONOR A whent tortilla fillad with house-roasted Crimini mushrooms,

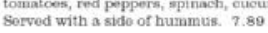

BLTE The classic BLT plus an over-hand cage-five Gg. Montoroy Jack and mayo on multigrain. 7.69

VEGOIE BURGER A sonsoned all-natuml patty of brown Tico, Peppadow peppers, onions, carrots and wocide latuce, tomato. red onion and a side of avocado, lestuce, tomato, red obion and a side of
Santa Fo sance. 8.19

GRILLED TURKEY Turkey, bacon, tomato and Monterey Jack with ranch dressing on grille

CHCKEN SALAD MEIT All-matural

whito-meat ohickon salad mado with applos.

faisins and colery servert open-faced on grilled

Monteroy Jack. 8.10
Salads made with fresh spring greens and served with artisan elabatta toust.

PECAN DIJON All-watural whiste-meat chickon ado, pecauss, tomato and carrots with Clbeddar and Monterey Jack. Drizsled witb warm honoy Dijon drossing: 8.3.

COBB Bacon, turkey, egg tomato avocalo and Sleu choose crumbles. Your oboico of dressing s. 8 SANTA PE Cajun all-astural white-meat ebickon broast, bouscrosusted Cringr musturcoms, tomatco and Montoroy Jack with Santa Po dregsing \&.38 FRUTTY CHICKEN Our all-natural white-meas chickon salnd soevod with baby spinach, tomato,

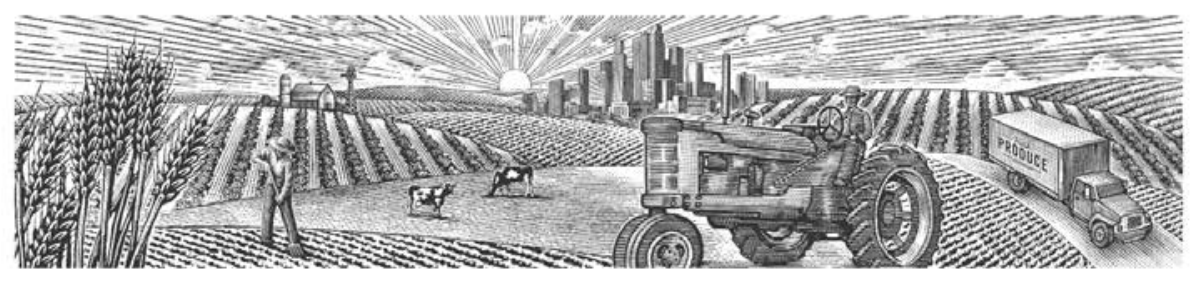

2 FOR YOU

LUNCH SPECIALS THAT ARE TWICE AS NICE 7.49

CHOOSE TWO FROM THE FOLLOWING

\begin{tabular}{|c|c|c|}
\hline SANOWICHES & SMLADS & SOUPS \\
\hline - Reuben & - Pecan Dijon & - Soup of the Da \\
\hline - Monterey Club & $\cdot \cos b$ & - Tomato Basij \\
\hline - Beofeater & - Dressed Greens & \\
\hline • Vegge Grill & - Sunta fe & \\
\hline - Grillad Turkey & & \\
\hline
\end{tabular}

\section{BEVERAGES}

\section{SIDES \& SMALL PLATES}

SUNRISE SELECT COPPEE An entire pot of our premium, full-alavored cotree

ICED COFPEV

HERBAL TEAS

A seloction of hot of granic herbal toes

нот CHосоLATE

LOW-FAT MILK Smail or Larget

100\% FRESH-SQUEEZED O

Small or Large

JUICES Apple, Gmpofruit, Cranberry and V8*

Small or large

BowL OF SOUP Tomato Basil or Soup of the Day 4.19

FRUIT BOWL Filled with frosh soasonal fruit Large 4.99 Small 3.98

FRESH, SEASONED POTATOES 9.99 ENGLISH MUPPIN OR TOAST 139

BAGEL With eroam oheses 1.90

PRESH BAKED MUFFIN OF THE DAY 2.49

HAM, BACON, SAUSAGE OR

VRESH-BREWED ICED TEA

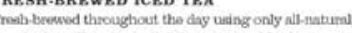

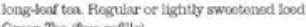

COCA-COLA Soft Drinks (froo xetllse)

S.PELLÉRINO (Sparkling)

Yeah, it's fresh.

Here at First Watch we begin each morning at the crack of dawn, slicing fresh fruits and vegretables, baking muffins and whipping up our French toast batter from scratch. Everything is made to order, and freshness is never compromised. We don't use heat lamps or deep fryers - we use only the finest ingredients possible for the freshest taste around.

Source: http://www.firstwatch.com/ 


\section{Exhibit 9: The Good Egg Menu}

\section{Good Egg :}

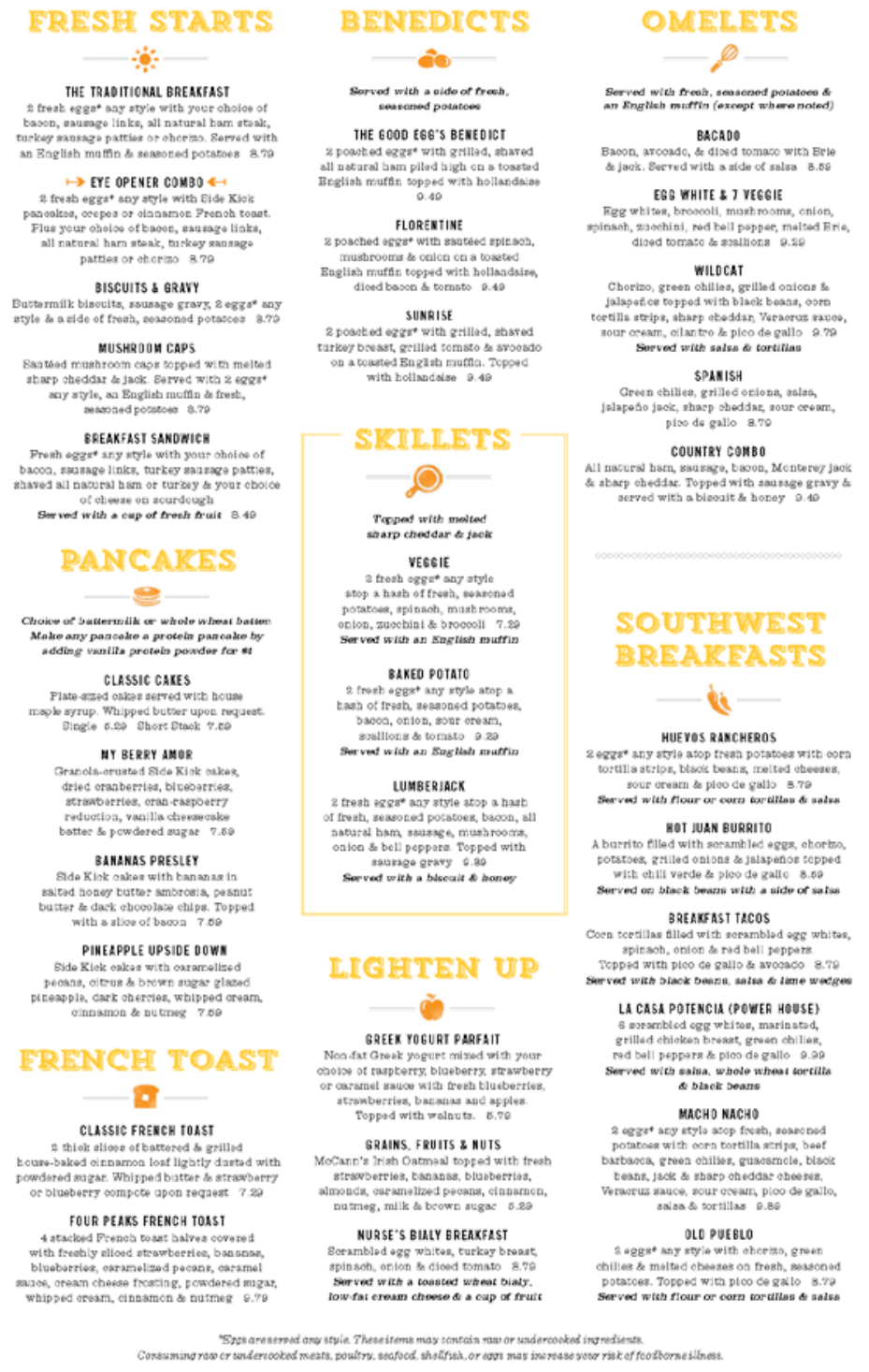




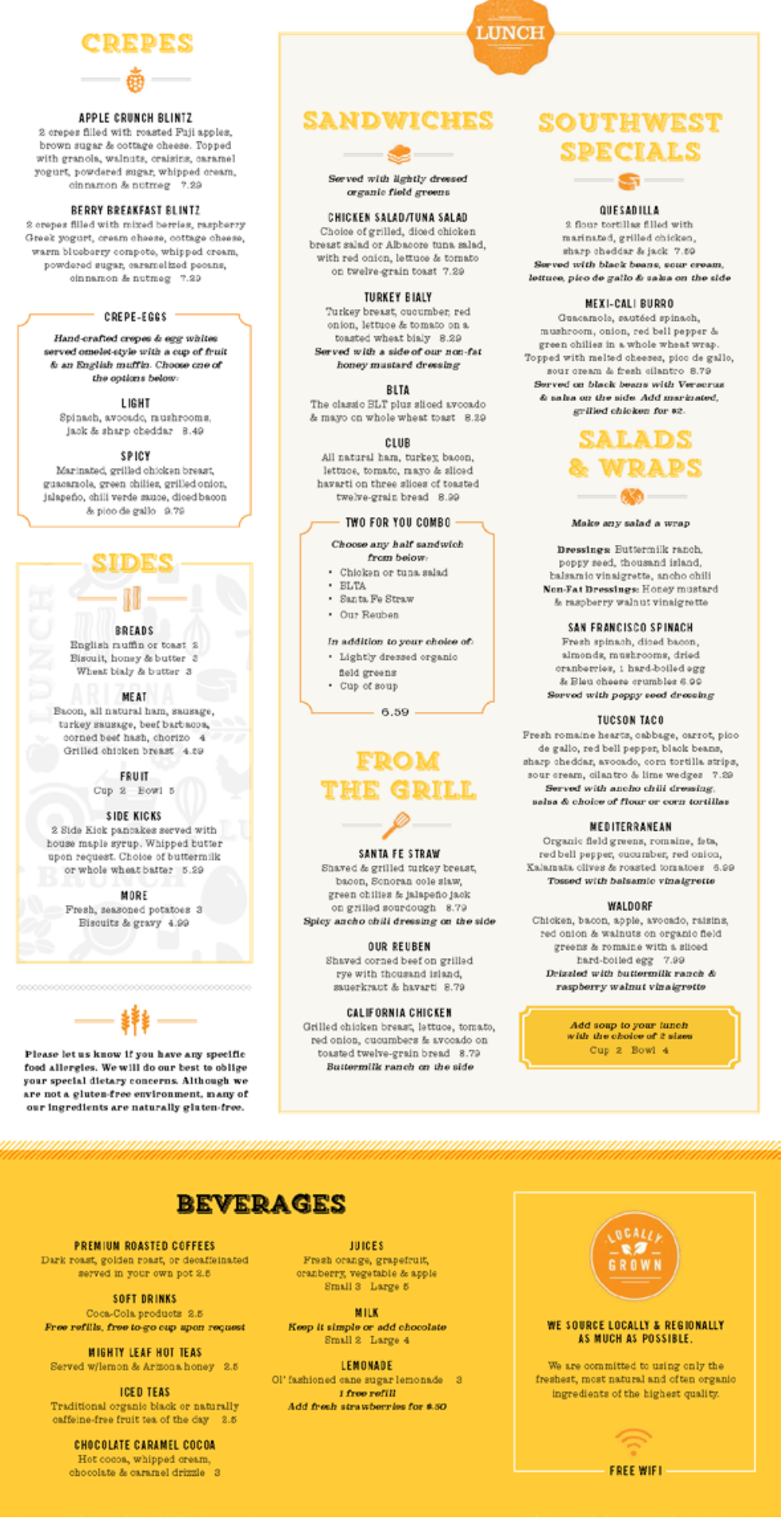

Source: http://thegoodeggaz/ 